\title{
Article \\ Chitosan-Based Antimicrobial Coating for Improving Postharvest Shelf Life of Pineapple
}

\author{
Indra Bhusan Basumatary $^{1} \mathbb{D}$, Avik Mukherjee ${ }^{1}$, Vimal Katiyar ${ }^{2}$, Santosh Kumar ${ }^{1, *(D)}$ and Joydeep Dutta ${ }^{3, * \mathbb{D}}$ \\ 1 Department of Food Engineering and Technology, Central Institute of Technology Kokrajhar, \\ Kokrajhar 783370, Assam, India; 023indra@gmail.com (I.B.B.); ak.mukherjee@cit.ac.in (A.M.) \\ 2 Department of Chemical Engineering, Indian Institute of Technology Guwahati, \\ Guwahati 781039, Assam, India; vkatiyar@iitg.ac.in \\ 3 Functional Materials, Department of Applied Physics, School of Engineering Sciences, KTH Royal Institute of \\ Technology, AlbaNova Universitets Centrum, Hannes Alfvéns väg 12, 11419 Stockholm, Sweden \\ * Correspondence: s.kumar@cit.ac.in (S.K.); joydeep@kth.se (J.D.)
}

Citation: Basumatary, I.B.;

Mukherjee, A.; Katiyar, V.; Kumar, S.; Dutta, J. Chitosan-Based

Antimicrobial Coating for Improving Postharvest Shelf Life of Pineapple.

Coatings 2021, 11, 1366. https://

doi.org/10.3390/ coatings11111366

Academic Editor: Alexandra

Muñoz-Bonilla

Received: 9 October 2021

Accepted: 2 November 2021

Published: 8 November 2021

Publisher's Note: MDPI stays neutral with regard to jurisdictional claims in published maps and institutional affiliations.

Copyright: (c) 2021 by the authors. Licensee MDPI, Basel, Switzerland. This article is an open access article distributed under the terms and conditions of the Creative Commons Attribution (CC BY) license (https:// creativecommons.org/licenses/by/ $4.0 /)$.

\begin{abstract}
Rapid postharvest losses and quality deteriorations in pineapple are major challenges to growers and handlers. Chitosan-based coatings on fruit surfaces have gained importance in recent years to enhance postharvest shelf life of the fruits. In this study, aloe vera gel was added as a natural antioxidant in chitosan-based composite coating containing $\mathrm{ZnO}$ nanoparticles. The developed formulation was applied on the surface of freshly harvested pineapple fruits. ZnO nanoparticles were used as an antimicrobial agent. Coated pineapple fruits were evaluated for weight loss, total soluble solids, titratable acidity, decay index, maturity index, and sensory attributes, including visual appearance, periodically at 5 day interval during storage. The results showed that the coating of the fruit reduced weight loss by about $5 \%$, and also delayed ripening and oxidative decay compared to the uncoated fruit. Thus, the developed coating formulation is a promising sustainable solution to reduce postharvest losses and to extend shelf life of pineapples.
\end{abstract}

Keywords: biopolymer; chitosan; aloe vera; ZnO NPs; nanocomposite; shelf life; antimicrobial coating; edible film and coating

\section{Introduction}

Pineapple (Ananus comosus) is one of the popular tropical fruits mostly exported by Costa Rica, Philippines, Brazil, Thailand, India, Indonesia, Chile, Ivory Coast, and South Africa, and its total production in India reached about 1.7 million tons in the year 2019 [1]. Pineapples have a unique flavor and taste and are rich in nutrients and antioxidants, which make them attractive to consumers due to their great health benefits. Pineapples are often introduced in the diet as a treatment or to prevent constipation because they increase bowel movement, improve intestinal health, and clean the kidneys $[2,3]$. Pineapple is a perishable fruit with short postharvest shelf life mainly due to a high rate of water loss, respiration, senescence, and ethylene production resulting in rapid ripening and deterioration [4,5]. Mostly fruits are packed and transported to destinations as quickly as possible, or stored under controlled cooled conditions. Various technologies such as modified atmosphere packaging (MAP) [6], synthetic wax coating [7], and salicylic acid treatment $[8,9]$ are used to enhance the shelf life of pineapple fruits. MAP is an expensive technique requiring high capital cost, whereas the others involving synthetic chemicals can potentially be harmful to consumers and for the environment in the long run [10].

In this context, application of biopolymer-based coatings on fruits and vegetables is gaining popularity for its efficacy in prolonging postharvest shelf life. Such coatings on fruit surfaces can effectively reduce weight loss, respiration, rate of maturity, and ripening [11-14]. Additionally, biopolymer-based coatings are generally non-toxic, biodegradable, biocompatible, environment-friendly, often edible, and may act as a carrier 
for active substances including antimicrobial and antioxidant agents [14]. The coating forms a thin layer on the fruit surface that acts as a protective barrier against gases and moisture, leading to a reduced rate of respiration and transpiration $[15,16]$. Several biopolymers such as chitosan, starch, alginate, carrageenan, soy protein, zein, and gelatin have been used for development of coating formulations for shelf-life extension of fruits [17-21]. Among them, chitosan is one of the well-studied biopolymers due to its inherent antimicrobial activity, abundant availability, low cost of manufacturing, good film-forming properties and environmentally friendly nature (Figure 1) [1,22-25]. Chitosan (CS) is a soluble form of chitin, and it is commercially obtained through partial deacetylation of chitin, which is extracted from crustacean and fish processing wastes [26]. Chitosan has inherent antimicrobial and antioxidant properties [14,27], but it is essential to enhance these functionalities in chitosan-based coatings to achieve improved results leading to higher shelf life of coated fruits. Improvement of shelf life of fruits such as guava [28], green tomato [29], longan fruit [30], plum [31], and strawberry [32] by applying chitosan-based coatings, alone or incorporated with active agents, has been reported in the literature.

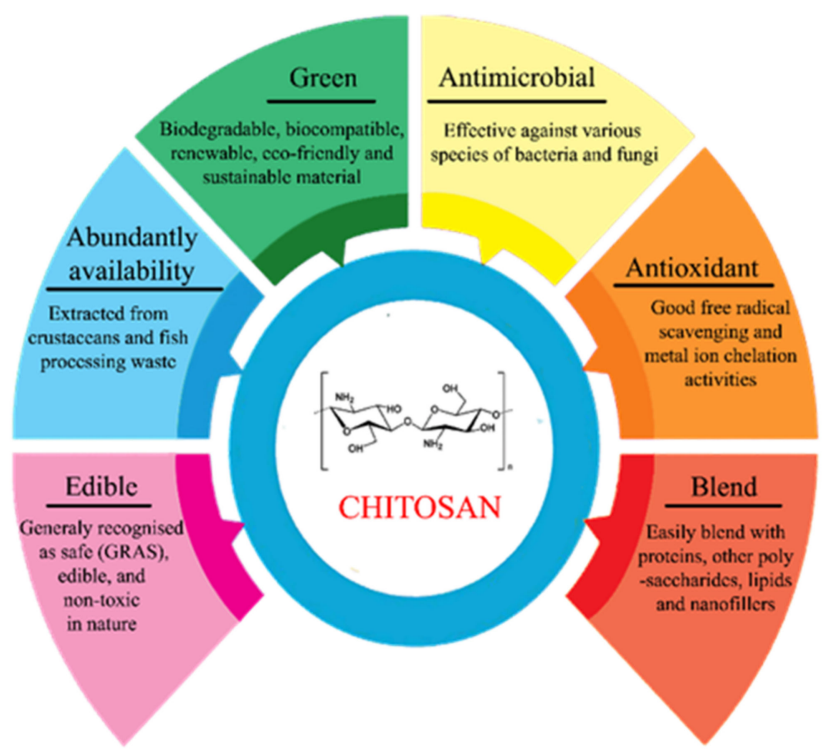

Figure 1. Chemical characteristics and functional properties of chitosan.

Aloe vera gel is a natural antimicrobial agent effective in hampering microbial membrane transportation [33,34]. Additionally, aloe vera gel has been used as a natural antioxidant for centuries, and it has been applied as an edible coating on fruits to prevent loss of moisture, to control respiratory rate and maturation, and to delay oxidative browning [34,35]. Zinc oxide nanoparticles ( $\mathrm{ZnO}$ NPs) are generally recognized as safe (GRAS) substances and have been well-studied as antimicrobial nanofillers that have tremendous potential as active agents in packaging films and coatings for food preservation [19]. Nanocomposite zinc-oxide-chitosan formulations have been reported to augment antimicrobial properties of packaging films with $63 \%$ reduction in bacterial counts in okra (Abelmoschus esculentus) after 12 days storage in the ambient atmosphere [36].

Thus, in this study, to prolong postharvest shelf life, chitosan-based coating to prevent moisture loss and firmness and control respiratory rate and maturation development was supplemented by aloe vera gel for delayed oxidative browning and zinc oxide $(\mathrm{ZnO})$ nanoparticles to reduce microorganism proliferation, thus delaying spoilage. This study focuses on the development of chitosan-based composite coating formulations for pineapple fruit and evaluates their effectiveness in enhancing postharvest shelf life of the coated/treated fruit. The effects of the coating treatment on physicochemical and sensory attributes and deterioration of pineapple fruits were studied periodically during 15 days storage in ambient conditions and reported herein. 


\section{Materials and Methods}

\subsection{Raw Materials and Chemicals}

Chitosan powder ( $\geq 90 \%$ deacetylation, low molecular weight; $50-200 \mathrm{KDa}$ ) was procured from Research Lab Fine Chem Industries, Mumbai, India. Hydrochloric acid $(\mathrm{HCl})$, sodium hydroxide $(\mathrm{NaOH})$, acetic acid $\left(\mathrm{CH}_{3} \mathrm{COOH}\right)$, and zinc oxide $(\mathrm{ZnO})$ nanopowder (particle size $<100 \mathrm{~nm}$ ) were supplied by Sigma Aldrich, Mumbai, India. Fresh aloe vera leaves were collected and brought to the laboratory, peeled, and then pulp was collected in a beaker. Pulp was ground with a spatula and the obtained gel was filtered using a muslin cloth and the filtrate was collected in a clean glass container and was termed as aloe vera gel (AVG). Healthy pineapple fruits without any physical injury and decay were collected from a fruit grower in Siliguri, India (latitude $26.7271^{\circ} \mathrm{N}$ and longitude $88.3953^{\circ} \mathrm{E}$ ).

\subsection{Preparation of Coating Formulation}

Coating formulations for postharvest treatment of pineapple fruits were prepared from chitosan $(\mathrm{CH})$, aloe vera gel (AVG), and zinc oxide nanoparticles (ZnO NPs). Initially, $700 \mathrm{~mL}$ of chitosan solution $(1 \%, w / v)$ was mixed with $1 \%$ acetic acid solution and the mixture was continuously stirred at $500 \mathrm{rpm}$ for $18 \mathrm{~h}$ on a magnetic stirrer (REMI, Mumbai, India). Equal volume of the $140 \mathrm{~mL}$ prepared chitosan solution was poured in five separate beakers. Next, $25 \%$ and $50 \%(w / w)$ of AVG were added and mixed well by continuous stirring on a magnetic stirrer at $1000 \mathrm{rpm}$ in each of the 2 pairs of beakers. The remaining $140 \mathrm{~mL}$ of the prepared chitosan solution was stored for later use for the reference chitosan coating. Coating formulations containing $25 \%$ and $50 \%$ AVG were further reinforced with $1 \mathrm{wt} . \% \mathrm{ZnO}$ NPs, and again mixed thoroughly under continuous stirring on a magnetic stirrer at $1000 \mathrm{rpm}$ for $15 \mathrm{~min}$. Thus, five different coating formulations, namely $\mathrm{CH}$ only, CH/AVG-25\%, CH/AVG-50\%, CH/AVG-25\%/ZnO-1\%, and CH/AVG-50\%/ZnO- $\%$ were prepared as summarized in Table 1.

Table 1. Composition of chitosan-based coating formulations containing aloe vera gel and $\mathrm{ZnO}$ nanoparticles.

\begin{tabular}{cccc}
\hline Coating Formulation & $\mathbf{C H} \%(w / v)$ & AVG\% $(w / w)$ & ZnO NPs\% (w/w) \\
\hline CH & 1 & 0 & 0 \\
CH/AVG-25 & 1 & 25 & 0 \\
CH/AVG-50 & 1 & 50 & 0 \\
$\mathrm{CH} / \mathrm{AVG}-25 / \mathrm{ZnO}-1$ & 1 & 25 & 1 \\
$\mathrm{CH} / \mathrm{AVG}-50 / \mathrm{ZnO}-1$ & 1 & 50 & 1 \\
\hline
\end{tabular}

\subsection{Application of the Prepared Coating Formulation on Pineapple Fruits}

Sixty pieces of fresh pineapple fruits of similar size, color, and maturity were collected, thoroughly washed with tap water, and then sanitized by dipping in aqueous $\mathrm{NaOCl}$ solution (200 ppm) for $2 \mathrm{~min}$. The fruits were then dried under an electric fan in ambient conditions. The washed and dried pineapple fruits were randomly distributed into 6 groups, each group having 10 fruits for coating/treatment with all the prepared formulations. Each group of pineapple fruits was coated/sprayed with the five different prepared coating formulations using a nozzle sprayer (Master Airbrush, San Diego, CA, USA). The sixth group of fruits was not coated and was considered as a control sample. The coated fruits were dried under an electric fan for $3 \mathrm{~h}$ in ambient conditions $\left(25^{\circ} \mathrm{C}\right.$ and $65 \% \mathrm{RH}$ ) to evaporate the excess moisture. After drying, each group of the pineapple fruits was placed in cardboard boxes and stored under ambient conditions for 15 days, and periodic physicochemical, sensory, and shelf-life observations were undertaken at every 5-day interval. The experiment was conducted in a completely randomized design in a $6 \times 4$ factorial scheme, considering 6 treatments; control (without coating), $\mathrm{CH}$, CH/AVG-25, CH/AVG-50, CH/AVG-25/ZnO-1, and CH/AVG-50/ZnO-1, and 4 evaluation periods; $0,5,10$, and 15 days. Fruits were examined by periodic measurement of 
weight loss, total soluble solids (TSS), titratable acidity (TA), color change, browning, and decay index.

\subsection{Physicochemical and Sensory Analysis of Coated/Treated Pineapple Fruits}

\subsubsection{Weight Loss}

The weight loss of the treated fruits was determined gravimetrically. The pineapple fruit samples were weighed before the treatment/coating and expressed as $W_{i}$, and weight after storage of the fruit at each time interval was expressed as $\mathrm{W}_{\mathrm{f}}$. The \% weight loss of the treated fruits was measured at each 5 day interval and determined using Equation (1):

$$
\text { Weight loss }(\%)=\left(\mathrm{W}_{\mathrm{i}}-\mathrm{W}_{\mathrm{f}}\right) / \mathrm{W}_{\mathrm{i}} \times 100
$$

where ' $W_{i}{ }^{\prime}$ and ' $W_{\mathrm{f}}$ ' are the initial and the final weight of the fruit samples, respectively.

\subsubsection{Total Soluble Solids (TSS) Content, Titratable Acidity (TA), and Maturity} Index (TSS/TA)

Total soluble solids (TSS) content was measured by a digital refractometer (Atago, Tokyo, Japan) and was expressed as percentage soluble solids. Titratable acidity (TA) was determined by the titration of pineapple juice with $0.1 \mathrm{~N} \mathrm{NaOH}$ to a $\mathrm{pH}$ of 8.1 , and expressed as grams of citric acid equivalents per liter of juice. Maturity index was expressed as the ratio of TSS/TA as described in the literature [37].

\subsubsection{Determination of Decay Index (DI)}

The degree of decay of treated fruits was expressed by decay index (DI). Fungal or bacterial growth symptoms on the fruit surface were observed visually by using a fourpoint scale, where $0=$ healthy fruit, $1=$ one very small lesion (beginning of infection), $2=$ one lesion less than $10 \mathrm{~mm}$ in diameter, $3=$ several lesions or $25 \%$ of fruit infected, $4=26 \%-50 \%$ of the treated fruit surface infected and quantified using Equation (2):

$$
\mathrm{DI}=\frac{\sum(\mathrm{DI} \text { rating } \times \text { no. of fruits at DI rating level })}{\text { Total number of treted fruits }}
$$

\subsubsection{Evaluation of Sensory Attributes}

Sensory characteristics of the coated/treated pineapple fruits were determined according to the method reported by Chen et al., 2019, with slight modifications [38]. Ten trained panelists (five men and five women: age between 20-35 years old) participated in the evaluation of sensory attributes such as sweetness, taste, odor, visual appearance, and overall quality of the treated and untreated pineapple fruits during ambient storage. All the panelists were pretrained to be familiar with the different sensory attributes of pineapple. A nine-point hedonic scale was used; $1=$ extremely poor, $3=$ poor, $5=$ acceptable, $7=\operatorname{good}$, $9=$ excellent, and a score of more than 5 was considered acceptable for consumption.

\subsubsection{Change in Visual Appearance of the Treated Pineapple}

Visual observation of the treated and untreated pineapple fruits was conducted by taking photographs of the whole and cut pineapple fruits periodically during storage under controlled lighting conditions. The color change, fungal growth, lesions, progress of ripening, and finally the deterioration in the fruits were monitored and recorded. The ripening stages of coated and uncoated/control pineapple fruits were determined by visual observation of fruit skin color. Visual observation of the treated and untreated pineapple fruits was conducted according to the method given by George et al., 2017, with slight modification based on the nine-point hedonic scale (9: liked very much; 5: not liked or disliked; 1 : disliked very much) which was structured to express the degree of acceptability for appearance. A score of more than 5 was considered visually acceptable. 


\subsection{Statistical Analysis}

All data were analyzed statistically by one-way ANOVA $(p \leq 0.05)$. Mean comparison was performed individually for each day using Tukey's test at significance level 0.05 . All the analysis was performed in triplicate, i.e., each analysis such as weight loss was performed three times using three different samples from the same fruit, and factorial design of the experiment was adopted each time. The data were processed using OriginPro $9.0 \mathrm{~s}$.

\section{Results and Discussion}

\subsection{Weight Loss of Treated Pineapple Fruits}

The weight loss in treated pineapple fruits during storage at ambient conditions is summarized in Table S1. It is evident from the results that application of only chitosan coating reduces the weight loss of pineapple fruits. However, addition of aloe vera gel in chitosan coating further enhanced the reduction in weight loss, which was directly proportional to the concentration of aloe vera gel added in the chitosan coating. When the pineapple fruits were treated with the $\mathrm{CH} / \mathrm{AVG}$ coating formulation reinforced with $\mathrm{ZnO}$ $\mathrm{NPs}$, it reduced the weight loss even further (Figure 2A). The uncoated pineapple and that treated with only $\mathrm{CH}$ coating showed $16.60 \%$ and $14.40 \%$ weight loss, respectively, whereas $\mathrm{CH} / \mathrm{AVG}-50$ - and CH/AVG-50/ZnO-1-coated fruits showed weight loss of only $11.56 \%$ and $11.40 \%$, respectively, after 15 days of storage. Thus, the coating (CH/AVG-50/ZnO-1) reduced weight loss of coated pineapple fruits by $5.2 \%$ compared to the uncoated fruits. Similar reduction in weight loss was also reported in mango fruits upon treatment with chitosan-based coatings incorporated with titanium dioxide $\left(\mathrm{TiO}_{2}\right)$ nanoparticles [11]. Many authors also reported the reduction of weight loss in green tomato, carrot, mango, and guava upon coating with chitosan formulation [11,29,39-41].
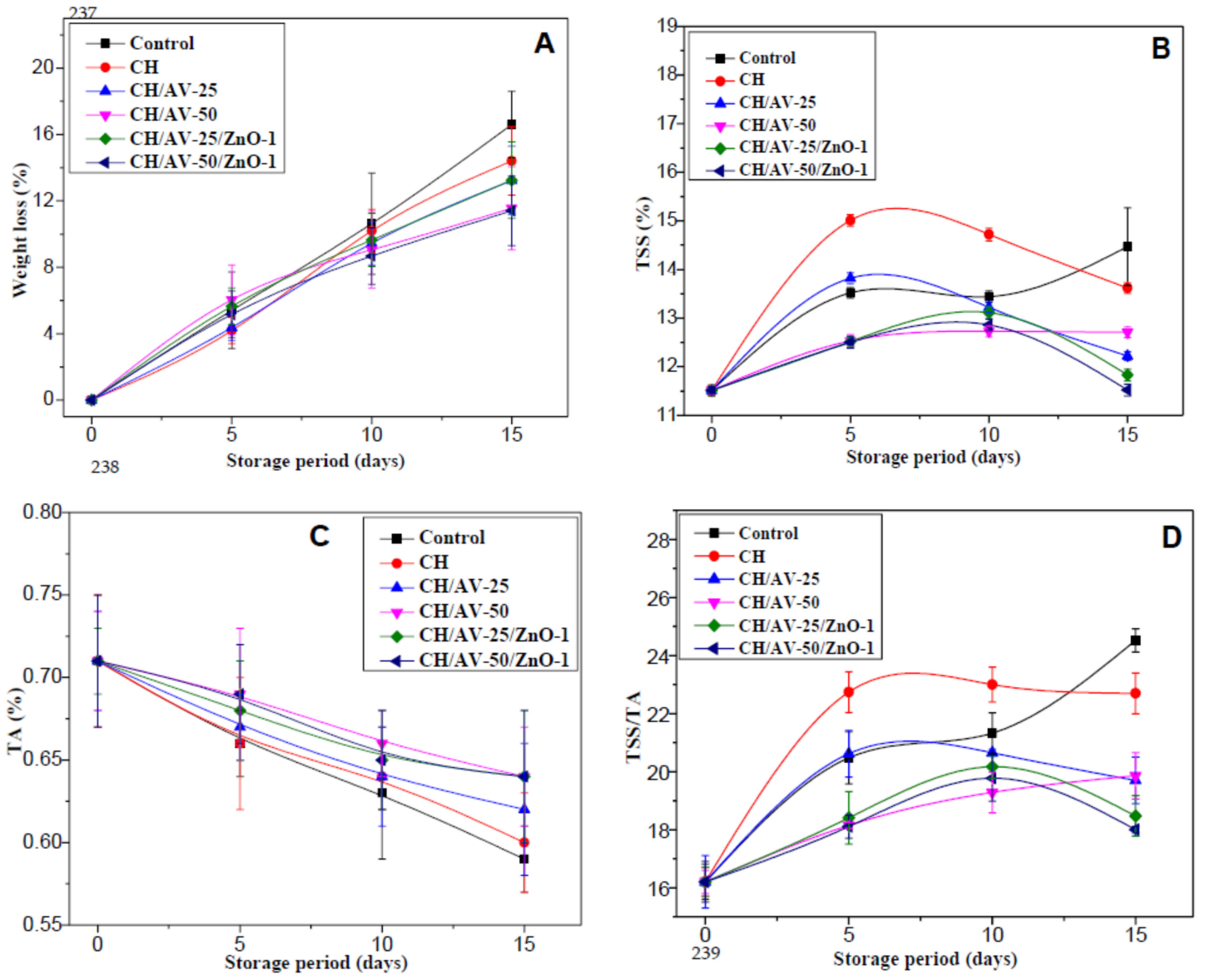

Figure 2. Effects of coating formulations on (A) weight loss, (B) TSS contents, (C) TA, and (D) maturity index (TSS/TA) of the treated and untreated pineapple fruit stored at ambient condition for 15 days. 


\subsection{Total Soluble Solids (TSS) of the Treated Pineapple}

Total soluble solids (TSS) mainly include sucrose, fructose, glucose, and other dissolved substances such as mineral, protein, and organic acids which are present in fruit juice. TSS contents of the treated and untreated pineapple fruits were measured periodically by Brix value determined via a refractometer (Table S1). It was observed that TSS of untreated fruit increased throughout the storage period (from 11.5 to $14.4 \%$ ), whereas in the coated fruits, the TSS values increased during the first 10 days and after 15 days of storage, the TSS values were almost the same as recorded at the onset prior to the coatings (TSS $=11.5 \%$ ). Pineapple fruits coated with $\mathrm{CH} / \mathrm{AVG}-50 / \mathrm{ZnO}-1$ formulation reduced loss in TSS by almost $2.97 \%$ (from $14.47 \%$ to $11.5 \%$ ), compared to the uncoated samples (Figure 2B). The increase in TSS concentration was perhaps due to loss of moisture during storage. The reduced TSS loss in coated fruits was due to the slower hydrolysis of carbohydrates to sugars, indicating slowing down of the respiration rate and metabolic activities [41]. Chitosan-based coatings on fruit surfaces act as a selective barrier preventing oxygen $\left(\mathrm{O}_{2}\right)$ and carbon dioxide $\left(\mathrm{CO}_{2}\right)$ permeability [42]. The obtained results are in agreement with the findings of other similar studies reported in the literature $[30,40]$.

\subsection{Titratable Acidity (TA) and Maturity Index of the Treated Pineapple}

Citric and malic acids are the major organic acids found in pineapple fruits responsible for the acidity, flavor, and taste of the fruit. Titratable acidity (TA) of coated and uncoated fruits decreased throughout the storage period, but the reduction in TA of the coated pineapples was comparatively lower (Figure 2C). At the end of 15 days storage, less reduction in TA value of the coated fruits was due to utilization of the acids present in the fruits as substrate during reverse glycolysis/respiration (Table S1). These results confirm that the chitosan composite coatings on pineapple fruits slow down the rate of respiration because of antioxidant activity of aloe vera gel and barrier properties of the coating upon treatment on the fruit surface. However, as expected, no significant effect on TA with $\mathrm{ZnO}$ NPs reinforcement in the coating was observed. The obtained results are similar to what has been reported for other fruits coated with chitosan-based composite coatings, such as strawberry [12], guava [13,40], and longan fruit [30].

Maturity of the coated and uncoated pineapple fruits increased throughout the storage period, indicating the ripening process (Figure 2D). However, the increase in maturity index in the coated pineapples was almost $27 \%$ lower (from 24.52 to 18.00 ) compared to uncoated fruits after 15 days storage (Table S1). Incorporation of aloe vera gel and $\mathrm{ZnO}$ NPs in the chitosan coating had a positive impact on delaying maturity and rate of ripening, thus enhancing postharvest shelf life of pineapple fruits. Similar trends were reported in the case of strawberry treated with chitosan/lemon essential oil composite coating [37].

\subsection{Decay Index}

Decay index of the treated and untreated pineapple fruits is shown in Table 2. The treated and untreated pineapple fruits gradually deteriorated during storage under ambient conditions. Initially, during the first 5 days of storage, no significant decay was observed in any fruit samples, whereas, after 10 days of storage, decay started in a few groups of pineapple samples. A few millimeter lesions were observed on the control, $\mathrm{CH}$ - and $\mathrm{CH} / \mathrm{AV}-25 / \mathrm{ZnO}-1$-coated pineapple fruits. The $\mathrm{CH} / \mathrm{AVG}-50 / \mathrm{ZnO}-1$-coated pineapple fruits showed only $25 \%$ decay compared to the control, whereas there was no decay observed in CH/AVG-50-coated fruit even after 15 days storage. The lower decay index in the case of chitosan coating containing aloe vera gel and ZnO NPs might be due to antifungal and antibacterial activity of aloe vera gel [43] and $\mathrm{ZnO}$ nanoparticle [44], which improved with increase in their concentrations. Similar results were also reported in our previous study, in which ZnO NPs were shown to improve antimicrobial properties of chitosan and agar-based nanocomposite films $[19,36]$. The antifungal and antibacterial activities of $\mathrm{ZnO}$ nanoparticles have been reported, and four possible mechanisms are suggested; (i) production of reactive oxygen species (ROS), (ii) loss of cellular integrity 
due to interaction of $\mathrm{ZnO}$ NPs with the microbial cell wall, (iii) release of $\mathrm{Zn}^{2+}$ ions, and (iv) entry of ZnO NPs into the microbial cell [45].

Table 2. Decay index (DI) of the treated and untreated pineapple fruits during ambient storage of 15 days.

\begin{tabular}{ccccc}
\hline Treatments & \multicolumn{4}{c}{ Decay Index (DI) } \\
\hline- & Day-0 & Day-5 & Day-10 & Day-15 \\
\hline Control & $0^{\mathrm{aA}}$ & $0^{\mathrm{aA}}$ & $0.50 \pm 0.12^{\mathrm{bB}}$ & $1.33 \pm 0.2^{\mathrm{cC}}$ \\
CH only & $0^{\mathrm{aA}}$ & $0^{\mathrm{aA}}$ & $0.25 \pm 0.07^{\mathrm{bAB}}$ & $0.66 \pm 0.11^{\mathrm{bBC}}$ \\
$\mathrm{CH} / \mathrm{AVG}-25$ & $0^{\mathrm{aA}}$ & $0^{\mathrm{aA}}$ & $0^{\mathrm{aA}}$ & $1.00 \pm 0.10^{\mathrm{bC}}$ \\
CH/AVG-50 & $0^{\mathrm{aA}}$ & $0^{\mathrm{aA}}$ & $0^{\mathrm{aA}}$ & $0^{\mathrm{aA}}$ \\
$\mathrm{CH} / \mathrm{AV}-25 \% / Z n O-1$ & $0^{\mathrm{aA}}$ & $0^{\mathrm{aA}}$ & $0.50 \pm 0.15^{\mathrm{bB}}$ & $0.66 \pm 0.04^{\mathrm{bBC}}$ \\
$\mathrm{CH} / \mathrm{AVG}-50 \% / Z n O-1$ & $0^{\mathrm{aA}}$ & $0^{\mathrm{aA}}$ & $0^{\mathrm{aA}}$ & $0.33 \pm 0.09^{\mathrm{bB}}$ \\
\hline
\end{tabular}

The values are expressed as means \pm SD of triplicate assays, and the lower case and upper case letters in superscript with the values indicate they are significantly different by LSD at $p<0.05$ between storage times in columns and treatments in rows, respectively.

\subsection{Sensory Qualities}

The results of sensory analysis of nanocomposite-coated and uncoated pineapple fruits stored in ambient conditions for 15 days are presented in Table 3. Sweetness of pineapple fruits increased during the entire period of storage in all the coated and uncoated groups of pineapples mainly due to maturation and weight loss of the fruits (Figure S1A). The taste of pineapple fruit consistently deteriorated for uncoated samples, and the score decreased to 4.2 at the end of 15 days storage. However, the taste characteristics were found to improve in the case of CH/AVG-50 (6.1), CH/AVG-25/ZnO-1 (6.2), and CH/AVG-50/ZnO-1 (6.2) coated pineapples, compared to the score on 0-day (5.8) (Figure S1B). Similar trends were also observed in the case of odor of the treated and untreated pineapple fruits (Figure S1C). The odor scores for CH/AVG-50-, CH/AVG-25/ZnO-1-, and CH/AVG-50/ZnO-1-coated samples after 15 days were 6.2,6.2, and 6.4, respectively, whereas that for the uncoated sample was only 3.7 (Table 3). The deterioration in odor or off flavor as suggested by the panelists in the case of uncoated and a few other coated pineapple fruits might be due to microbial spoilage, which did not occur in the case of the fruits coated with the above-mentioned coatings. Visual appearance scores of the coated and uncoated pineapple fruits decreased throughout the 15-day storage period in all samples, but the fruits coated with CH/AVG-50, CH/AVG-25/ZnO-1, and CH/AVG-50/ZnO-1 showed acceptable appearance even after 15 days (Figure S1D). Overall acceptance scores for all samples were maintained during the first 5 days of storage, and gradually decreased thereafter. However, the overall acceptance scores for CH/AV-50-, CH/AV-25/ZnO-1-, and CH/AV-50/ $\mathrm{ZnO}-1$-coated pineapple fruits were 7.2, 7.3, and 7.5, respectively, which were maintained and comparable with that of 0 -day (7.8) (Table 3). In conclusion, the pineapple fruits treated with $\mathrm{CH} / \mathrm{AV}-50, \mathrm{CH} / \mathrm{AV}-25 / \mathrm{ZnO}-1$, and $\mathrm{CH} / \mathrm{AV}-50 / \mathrm{ZnO}-1$ composite coatings showed better maintenance of all the sensory attributes even after 15 days of storage, which is supported by findings of similar studies $[46,47]$. 
Table 3. Values for sensorial attributes of coated and uncoated pineapple fruits stored at ambient condition for 15 days.

\begin{tabular}{|c|c|c|c|c|c|c|c|}
\hline \multirow[b]{2}{*}{ Parameter } & \multirow{2}{*}{$\begin{array}{l}\text { Storage Period } \\
\text { (Days) }\end{array}$} & \multicolumn{6}{|c|}{ Treatments } \\
\hline & & Control & CH Only & CH/AV-25 & CH/AV-50 & $\begin{array}{c}\text { CH/AV-25/ } \\
\text { ZnO-1 }\end{array}$ & $\begin{array}{l}\text { CH/AV-50/ } \\
\text { ZnO-1 }\end{array}$ \\
\hline \multirow{4}{*}{ Sweetness } & 0 & $5.72 \pm 0.17^{\mathrm{aA}}$ & $5.72 \pm 0.17^{\mathrm{aA}}$ & $5.72 \pm 0.17^{\mathrm{aA}}$ & $5.72 \pm 0.17^{\mathrm{aA}}$ & $5.72 \pm 0.17^{\mathrm{aA}}$ & $5.72 \pm 0.17^{\mathrm{aA}}$ \\
\hline & 5 & $5.81 \pm 0.25^{\mathrm{aAB}}$ & $6.07 \pm 0.22 \mathrm{aA}$ & $6.52 \pm 0.20^{\mathrm{aB}}$ & $6.07 \pm 0.12^{\mathrm{aA}}$ & $5.93 \pm 0.18^{\mathrm{aA}}$ & $6.01 \pm 0.16^{\mathrm{aA}}$ \\
\hline & 10 & $6.51 \pm 0.17 \mathrm{abB}$ & $6.20 \pm 0.21^{\mathrm{aA}}$ & $7.32 \pm 0.09 \mathrm{bC}$ & $6.40 \pm 0.12^{\mathrm{abA}}$ & $6.63 \pm 0.13^{\mathrm{abB}}$ & $7.24 \pm 0.20^{\mathrm{bB}}$ \\
\hline & 15 & $6.54 \pm 0.18^{\mathrm{aB}}$ & $7.11 \pm 0.12^{\mathrm{abB}}$ & $7.51 \pm 0.20 \mathrm{bC}$ & $7.53 \pm 0.15^{\mathrm{bB}}$ & $6.87 \pm 0.13^{\mathrm{abB}}$ & $7.16 \pm 0.22 \mathrm{abB}$ \\
\hline \multirow{4}{*}{ Taste } & 0 & $5.80 \pm 0.11^{\mathrm{aA}}$ & $5.80 \pm 0.11^{\mathrm{aA}}$ & $5.80 \pm 0.11^{\mathrm{aA}}$ & $5.80 \pm 0.11^{\mathrm{aA}}$ & $5.80 \pm 0.11^{\mathrm{aA}}$ & $5.80 \pm 0.11^{\mathrm{aA}}$ \\
\hline & 5 & $5.72 \pm 0.09^{\mathrm{aA}}$ & $6.57 \pm 0.13^{\mathrm{bB}}$ & $6.13 \pm 0.07^{\mathrm{aA}}$ & $5.74 \pm 0.09 \mathrm{aA}$ & $5.86 \pm 0.14^{\mathrm{aA}}$ & $5.83 \pm 0.12^{\mathrm{aA}}$ \\
\hline & 10 & $5.13 \pm 0.12^{\mathrm{aB}}$ & $5.67 \pm 0.07^{\mathrm{aA}}$ & $7.01 \pm 0.09 \mathrm{cB}$ & $6.21 \pm 0.07^{\mathrm{bA}}$ & $6.59 \pm 0.08^{b c B}$ & $7.75 \pm 0.04 \mathrm{~dB}$ \\
\hline & 15 & $4.29 \pm 0.12^{\mathrm{aC}}$ & $5.05 \pm 0.09 \mathrm{bC}$ & $5.73 \pm 0.12^{\mathrm{cA}}$ & $6.13 \pm 0.13^{\mathrm{cA}}$ & $6.22 \pm 0.14^{\mathrm{cA}}$ & $6.23 \pm 0.06^{\mathrm{cA}}$ \\
\hline \multirow{4}{*}{ Odor } & 0 & $5.60 \pm 0.16^{\mathrm{aA}}$ & $5.60 \pm 0.16^{\mathrm{aA}}$ & $5.60 \pm 0.16^{\mathrm{aA}}$ & $5.60 \pm 0.16^{\mathrm{aA}}$ & $5.60 \pm 0.16^{\mathrm{aA}}$ & $5.60 \pm 0.16^{\mathrm{aA}}$ \\
\hline & 5 & $5.57 \pm 0.09 \mathrm{aA}$ & $5.82 \pm 0.11^{\mathrm{aA}}$ & $5.75 \pm 0.18^{\mathrm{aA}}$ & $5.83 \pm 0.14^{\mathrm{aA}}$ & $5.85 \pm 0.16^{\mathrm{aA}}$ & $5.67 \pm 0.14^{\mathrm{aA}}$ \\
\hline & 10 & $5.43 \pm 0.18^{\mathrm{aA}}$ & $6.58 \pm 0.13^{\mathrm{bB}}$ & $6.23 \pm 0.13^{\mathrm{abA}}$ & $6.33 \pm 0.11^{\mathrm{bA}}$ & $6.28 \pm 0.10^{\mathrm{abA}}$ & $6.21 \pm 0.13^{\mathrm{abA}}$ \\
\hline & 15 & $3.76 \pm 0.16^{\mathrm{aB}}$ & $5.06 \pm 0.09 \mathrm{bA}$ & $5.32 \pm 0.12^{\mathrm{bA}}$ & $6.26 \pm 0.11^{\mathrm{cA}}$ & $6.25 \pm 0.14^{\mathrm{cA}}$ & $6.47 \pm 0.08^{\mathrm{cB}}$ \\
\hline \multirow{4}{*}{$\begin{array}{c}\text { Visual } \\
\text { appearance }\end{array}$} & 0 & $9.00 \pm 0.08^{\mathrm{aA}}$ & $9.00 \pm 0.08^{\mathrm{aA}}$ & $9.00 \pm 0.08^{\mathrm{aA}}$ & $9.00 \pm 0.08^{\mathrm{aA}}$ & $9.00 \pm 0.08^{\mathrm{aA}}$ & $9.00 \pm 0.08^{\mathrm{aA}}$ \\
\hline & 5 & $8.25 \pm 0.05^{\mathrm{aB}}$ & $8.07 \pm 0.07 \mathrm{aB}$ & $8.16 \pm 0.05^{\mathrm{aB}}$ & $8.13 \pm 0.04 \mathrm{aB}$ & $7.84 \pm 0.06^{\mathrm{aB}}$ & $7.81 \pm 0.08^{\mathrm{bB}}$ \\
\hline & 10 & $6.51 \pm 0.09 \mathrm{aC}$ & $7.21 \pm 0.14 \mathrm{bC}$ & $7.63 \pm 0.09 \mathrm{bcC}$ & $7.84 \pm 0.04^{\mathrm{cC}}$ & $7.66 \pm 0.05^{\mathrm{bcB}}$ & $7.8 \pm 0.04 \mathrm{cB}$ \\
\hline & 15 & $4.24 \pm 0.10^{\mathrm{aD}}$ & $5.16 \pm 0.12^{\mathrm{bD}}$ & $6.20 \pm 0.15^{\mathrm{cD}}$ & $7.24 \pm 0.06^{\mathrm{dD}}$ & $7.63 \pm 0.10 \mathrm{~dB}$ & $7.55 \pm 0.07 \mathrm{~dB}$ \\
\hline \multirow{4}{*}{$\begin{array}{l}\text { Overall } \\
\text { acceptance }\end{array}$} & 0 & $7.80 \pm 0.10^{\mathrm{aA}}$ & $7.80 \pm 0.10^{\mathrm{aA}}$ & $7.80 \pm 0.10^{\mathrm{aA}}$ & $7.80 \pm 0.10^{\mathrm{aA}}$ & $7.80 \pm 0.10^{\mathrm{aA}}$ & $7.80 \pm 0.10^{\mathrm{aA}}$ \\
\hline & 5 & $8.18 \pm 0.14^{\mathrm{aA}}$ & $7.83 \pm 0.21^{\mathrm{aA}}$ & $8.18 \pm 0.11^{\mathrm{aA}}$ & $8.15 \pm 0.12^{\mathrm{aA}}$ & $7.90 \pm 0.14^{\mathrm{aA}}$ & $7.95 \pm 0.05^{\mathrm{aA}}$ \\
\hline & 10 & $5.72 \pm 0.12^{\mathrm{aB}}$ & $6.23 \pm 0.22^{\mathrm{aB}}$ & $6.47 \pm 0.11^{\mathrm{bB}}$ & $6.83 \pm 0.15^{\mathrm{bcB}}$ & $7.25 \pm 0.13^{\mathrm{cA}}$ & $7.25 \pm 0.12^{\mathrm{cA}}$ \\
\hline & 15 & $4.13 \pm 0.11^{\mathrm{aC}}$ & $5.65 \pm 0.06^{\mathrm{bB}}$ & $6.77 \pm 0.12^{\mathrm{cB}}$ & $7.22 \pm 0.08^{c B}$ & $7.30 \pm 0.11^{\mathrm{cA}}$ & $7.54 \pm 0.18^{\mathrm{cA}}$ \\
\hline
\end{tabular}

The values are expressed as means \pm SD of triplicate assays, and the lower case and upper case letters in superscript with the values indicate they are significantly different by LSD at $p<0.05$ between treatments in columns and storage times in rows, respectively.

\subsection{Visual Observation of the Treated Pineapple Fruits}

Visual observation of the treated pineapple was carried out to monitor the color change, fungal growth, lesions, progress of ripening, and finally the deterioration in fruits. The color of the skin of pineapple fruit is an excellent indicator to monitor the ripening of the fruits. It has been observed that the color of the treated and untreated pineapple changes from green to yellow and then to brown or orange during storage (Figure 3). The uncoated (control) pineapple showed rapid color changes and attained brown color more rapidly than the coated pineapple fruits. In the case of CH/AVG-50-, $\mathrm{CH} / \mathrm{AVG}-25 / \mathrm{ZnO}-1-$, and CH/AVG-50/ZnO-1-coated pineapples, the yellow color and fresh appearance were maintained even after 15 days of storage (Figure 3). Similar trends were also observed in the internal tissues when fruits were cut (Figure 4). It is evident from the figure that damage occurs in $20 \%-30 \%$ of the internal tissues in the case of uncoated, $\mathrm{CH}$-, and $\mathrm{CH} / \mathrm{AVG}-25$-coated fruits, whereas such damages are not visible in the case of CH/AVG-50-, CH/AVG-25/ZnO-1-, and CH/AVG-50/ZnO-1-coated pineapples (Figure 4). This is perhaps due to protective effects of the nanocomposite coatings because they consist of antimicrobial and antioxidant agents ( $\mathrm{ZnO}$ NPs and aloe vera gel). In addition, the coatings help to reduce water loss, respiration rate, gaseous exchange, and metabolic activities, thus extending the postharvest shelf life of the coated fruits. The improvements achieved in postharvest life of pineapple fruits in this study by applying sustainable coatings developed from chitosan, aloe vera gel, and ZnO NPs are comparable to those reported in the literature using a synthetic commercial wax (Sta-Fresh 2952) [7]. 




Figure 3. Effect of chitosan-based coatings on color, ripening, and maturity of pineapple fruits during 15 days storage under ambient condition.

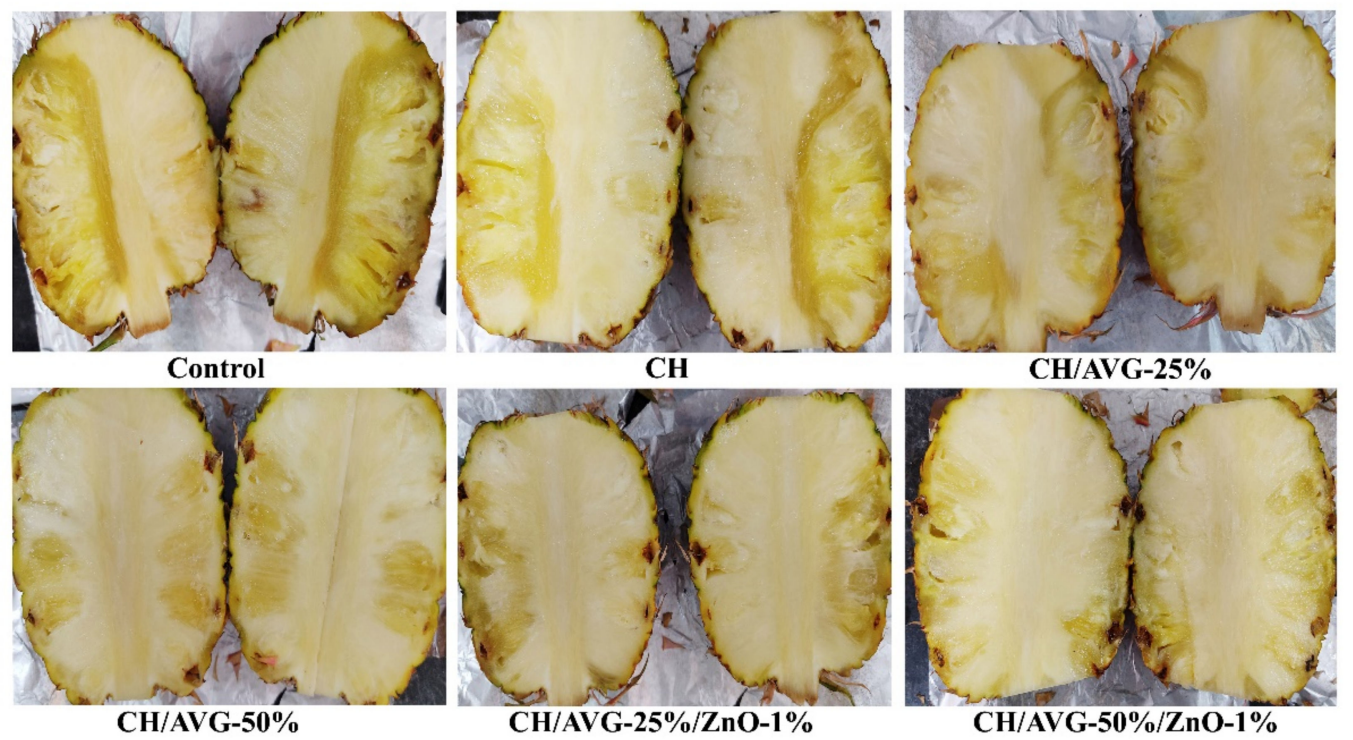

Figure 4. Effect of chitosan-based coatings on internal tissue damage and deterioration of pineapple fruits during 15 days storage under ambient condition. 


\section{Conclusions}

In this study, novel and smart nanocomposite coatings were developed from chitosan, aloe vera, and $\mathrm{ZnO}$ nanoparticles for prolonging postharvest life of pineapple fruit. Aloe vera and $\mathrm{ZnO}$ nanoparticles were incorporated in chitosan matrix as active agents to further increase the antimicrobial and antioxidant activities of chitosan. The developed coating reduced weight loss by $\sim 5.2 \%$, TSS losses by $\sim 2.97 \%$, and maturity by $\sim 27 \%$ in the coated pineapple during 15 days of storage in ambient condition. Addition of aloe vera and $\mathrm{ZnO}$ NPs into the chitosan coating not only slows down the fruit ripening but also maintains the sensory attributes of pineapple fruit at acceptable levels. Thus, the developed coating formulations can be a sustainable and smart solution to maintain postharvest quality and extend shelf life of pineapples.

Supplementary Materials: The following are available online at https://www.mdpi.com/article/ 10.3390/ coatings11111366/s1, Figure S1: Effects of coating formulations on sensory attribute scores; (A) sweetness, (B) taste, (C) odor, and (D) visual appearance of the treated and untreated pineapple fruit during 15 days storage at ambient condition, Table S1: Values of weight loss, total soluble solid (TSS), titratable acidity (TA), and maturity index (TSS/TA) of the coated and uncoated pineapple fruits during storage for 15 days at ambient condition.

Author Contributions: Conceptualization, I.B.B., A.M., V.K. and S.K.; study design, I.B.B., A.M., V.K. and S.K.; formal analysis, I.B.B. and S.K.; investigation, I.B.B., A.M., V.K., J.D. and S.K.; writing—original draft preparation, I.B.B., A.M. and S.K.; writing—review and editing, S.K., V.K. and J.D.; supervision, S.K. and V.K.; funding acquisition, S.K. and V.K. All authors have read and agreed to the published version of the manuscript.

Funding: This research was funded by Department of Biotechnology (DBT), Ministry of Science and Technology, Govt. of India with No. BT/COE/34/SP28408/2018 for providing necessary financial support.

Institutional Review Board Statement: Not applicable.

Informed Consent Statement: Not applicable.

Data Availability Statement: Experimental data generated at Department of Food Engineering and Technology, Central Institute of Technology Kokrajhar, Assam (India) are available from the corresponding author on request.

Acknowledgments: S.K. and V.K. acknowledge 'Sunrise Career Project (Ref: NECBH/2019-20/173)' under North East Centre for Biological Sciences and Healthcare Engineering (NECBH) Twinning Outreach Programme hosted by Indian Institute of Technology Guwahati (IITG), Guwahati, Assam funded by Department of Biotechnology (DBT), Ministry of Science and Technology, Govt. of India with number BT/COE/34/SP28408/2018 for providing necessary financial support.

Conflicts of Interest: The authors declare no conflict of interest.

\section{References}

1. Leading Countries in Pineapple Production Worldwide in 2019. Available online: https:/ / www.statista.com/statistics/298517 /global-pineapple-production-by-leading-countries/ (accessed on 4 November 2021).

2. Farid Hossain, M. Nutritional value and medicinal benefits of pineapple. Int. J. Nutr. Food Sci. 2015, 4, 84-88. [CrossRef]

3. Mohd Ali, M.; Hashim, N.; Abd Aziz, S.; Lasekan, O. Pineapple (Ananas comosus): A comprehensive review of nutritional values, volatile compounds, health benefits, and potential food products. Food Res. Int. 2020, 137, 109675. [CrossRef] [PubMed]

4. Paull, R.E.; Chen, N.J. Chapter 17.4-Tropical fruits: Pineapples. In Controlled and Modified Atmospheres for Fresh and Fresh-Cut Produce; Gil, M.I., Beaudry, R., Eds.; Academic Press: Cambridge, MA, USA, 2020; pp. 381-388.

5. Montero-Calderón, M.; Rojas-Graü, M.A.; Martín-Belloso, O. Effect of packaging conditions on quality and shelf-life of fresh-cut pineapple (Ananas comosus). Postharvest Biol. Technol. 2008, 50, 182-189. [CrossRef]

6. Budu, A.S.; Joyce, D.C. Effect of modified atmosphere packaging on the quality of minimally processed pineapple cv. 'Smooth Cayenne' fruit. J. Hortic. Sci. Biotechnol. 2015, 80, 193-198. [CrossRef]

7. Li, X.; Zhu, X.; Wang, H.; Lin, X.; Lin, H.; Chen, W. Postharvest application of wax controls pineapple fruit ripening and improves fruit quality. Postharvest Biol. Technol. 2018, 136, 99-110. [CrossRef]

8. Lu, X.; Sun, D.; Li, Y.; Shi, W.; Sun, G. Pre- and post-harvest salicylic acid treatments alleviate internal browning and maintain quality of winter pineapple fruit. Sci. Hortic. 2011, 130, 97-101. [CrossRef] 
9. Sayyari, M.; Babalar, M.; Kalantari, S.; Serrano, M.; Valero, D. Effect of salicylic acid treatment on reducing chilling injury in stored pomegranates. Postharvest Biol. Technol. 2009, 53, 152-154. [CrossRef]

10. Youryon, P.; Supapvanich, S.; Kongtrakool, P.; Wongs-Aree, C. Calcium chloride and calcium gluconate peduncle infiltrations alleviate the internal browning of Queen pineapple in refrigerated storage. Hortic. Environ. Biotechnol. 2018, 59, 205-213. [CrossRef]

11. Xing, Y.; Yang, H.; Guo, X.; Bi, X.; Liu, X.; Xu, Q.; Wang, Q.; Li, W.; Li, X.; Shui, Y.; et al. Effect of chitosan/Nano-TiO 2 composite coatings on the postharvest quality and physicochemical characteristics of mango fruits. Sci. Hortic. 2020, 263, 109135. [CrossRef]

12. Riaz, A.; Aadil, R.M.; Amoussa, A.M.O.; Bashari, M.; Abid, M.; Hashim, M.M. Application of chitosan-based apple peel polyphenols edible coating on the preservation of strawberry (Fragaria ananassa cv Hongyan) fruit. J. Food Process. Preserv. 2020, 45, e15018. [CrossRef]

13. Hong, K.; Xie, J.; Zhang, L.; Sun, D.; Gong, D. Effects of chitosan coating on postharvest life and quality of guava (Psidium guajava L.) fruit during cold storage. Sci. Hortic. 2012, 144, 172-178. [CrossRef]

14. Basumatary, I.B.; Mukherjee, A.; Katiyar, V.; Kumar, S. Biopolymer-based nanocomposite films and coatings: Recent advances in shelf-life improvement of fruits and vegetables. Crit. Rev. Food Sci. Nutr. 2020, 1-24. [CrossRef] [PubMed]

15. Kumar, S.; Ye, F.; Dobretsov, S.; Dutta, J. Chitosan nanocomposite coatings for food, paints, and water treatment applications. Appl. Sci. 2019, 9, 2409. [CrossRef]

16. Salehi, F. Edible coating of fruits and vegetables using natural gums: A review. Int. J. Fruit Sci. 2020, 20, S570-S589. [CrossRef]

17. Kumar, S.; Mudai, A.; Roy, B.; Basumatary, I.B.; Mukherjee, A.; Dutta, J. Biodegradable hybrid nanocomposite of chitosan/gelatin and green synthesized zinc oxide nanoparticles for food packaging. Foods 2020, 9, 1143. [CrossRef] [PubMed]

18. Kumar, S.; Mitra, A.; Halder, D. Centella asiatica leaf mediated synthesis of silver nanocolloid and its application as filler in gelatin based antimicrobial nanocomposite film. LWT 2017, 75, 293-300. [CrossRef]

19. Kumar, S.; Boro, J.C.; Ray, D.; Mukherjee, A.; Dutta, J. Bionanocomposite films of agar incorporated with ZnO nanoparticles as an active packaging material for shelf life extension of green grape. Heliyon 2019, 5, e01867. [CrossRef] [PubMed]

20. Díaz-Mula, H.M.; Serrano, M.; Valero, D. Alginate coatings preserve fruit quality and bioactive compounds during storage of sweet cherry fruit. Food Bioprocess Technol. 2012, 5, 2990-2997. [CrossRef]

21. Moreno, M.A.; Orqueda, M.E.; Gómez-Mascaraque, L.G.; Isla, M.I.; López-Rubio, A. Crosslinked electrospun zein-based food packaging coatings containing bioactive chilto fruit extracts. Food Hydrocoll. 2019, 95, 496-505. [CrossRef]

22. Al-Naamani, L.; Dobretsov, S.; Dutta, J. Chitosan-zinc oxide nanoparticle composite coating for active food packaging applications. Innov. Food Sci. Emerg. Technol. 2016, 38, 231-237. [CrossRef]

23. Kumar, S.; Mukherjee, A.; Dutta, J. Chitosan based nanocomposite films and coatings: Emerging antimicrobial food packaging alternatives. Trends Food Sci. Technol. 2020, 97, 196-209. [CrossRef]

24. Kumar, S.; Shukla, A.; Baul, P.P.; Mitra, A.; Halder, D. Biodegradable hybrid nanocomposites of chitosan/gelatin and silver nanoparticles for active food packaging applications. Food Packag. Shelf Life 2018, 16, 178-184. [CrossRef]

25. Kerch, G. Chitosan films and coatings prevent losses of fresh fruit nutritional quality: A review. Trends Food Sci. Technol. 2015, 46, 159-166. [CrossRef]

26. Boudouaia, N.; Bengharez, Z.; Jellali, S. Preparation and characterization of chitosan extracted from shrimp shells waste and chitosan film: Application for eriochrome black T removal from aqueous solutions. Appl. Water Sci. 2019, 9, 91. [CrossRef]

27. Kumar, S.; Ye, F.; Mazinani, B.; Dobretsov, S.; Dutta, J. Chitosan nanocomposite coatings containing chemically resistant ZnO-SnO $x$ core-shell nanoparticles for photocatalytic antifouling. Int. J. Mol. Sci. 2021, 22, 4513. [CrossRef]

28. Nair, M.S.; Saxena, A.; Kaur, C. Effect of chitosan and alginate based coatings enriched with pomegranate peel extract to extend the postharvest quality of guava (Psidium guajava L.). Food Chem. 2018, 240, 245-252. [CrossRef]

29. Zhu, Y.; Li, D.; Belwal, T.; Li, L.; Chen, H.; Xu, T.; Luo, Z. Effect of nano-SiOx/chitosan complex coating on the physicochemical characteristics and preservation performance of green tomato. Molecules 2019, 24, 4552. [CrossRef]

30. Shi, S.; Wang, W.; Liu, L.; Wu, S.; Wei, Y.; Li, W. Effect of chitosan/nano-silica coating on the physicochemical characteristics of longan fruit under ambient temperature. J. Food Eng. 2013, 118, 125-131. [CrossRef]

31. Kumar, P.; Sethi, S.; Sharma, R.R.; Srivastav, M.; Varghese, E. Effect of chitosan coating on postharvest life and quality of plum during storage at low temperature. Sci. Hortic. 2017, 226, 104-109. [CrossRef]

32. Pavinatto, A.; de Almeida Mattos, A.V.; Malpass, A.C.G.; Okura, M.H.; Balogh, D.T.; Sanfelice, R.C. Coating with chitosan-based edible films for mechanical/biological protection of strawberries. Int. J. Biol. Macromol. 2020, 151, 1004-1011. [CrossRef]

33. Goudarzi, M.; Fazeli, M.; Azad, M.; Seyedjavadi, S.S.; Mousavi, R. Aloe vera Gel: Effective therapeutic agent against multidrugresistant pseudomonas aeruginosa isolates recovered from burn wound infections. Chemother. Res. Pract. 2015, 2015, 639806. [CrossRef]

34. Hassanpour, H. Effect of Aloe vera gel coating on antioxidant capacity, antioxidant enzyme activities and decay in raspberry fruit. LWT-Food Sci. Technol. 2015, 60, 495-501. [CrossRef]

35. Misir, J.; Brishti, F.H.; Hoque, M.M. Aloe vera gel as a novel edible coating for fresh fruits: A review. Am. J. Food Sci. Technol. 2014, 2, 93-97. [CrossRef]

36. Al-Naamani, L.; Dutta, J.; Dobretsov, S. Nanocomposite zinc oxide-chitosan coatings on polyethylene films for extending storage life of okra (abelmoschus esculentus). Nanomaterials 2018, 8, 479. [CrossRef] [PubMed] 
37. Perdones, A.; Sánchez-González, L.; Chiralt, A.; Vargas, M. Effect of chitosan-lemon essential oil coatings on storage-keeping quality of strawberry. Postharvest Biol. Technol. 2012, 70, 32-41. [CrossRef]

38. Chen, H.; Sun, Z.; Yang, H. Effect of carnauba wax-based coating containing glycerol monolaurate on the quality maintenance and shelf-life of Indian jujube (Zizyphus mauritiana Lamk.) fruit during storage. Sci. Hortic. 2019, 244, 157-164. [CrossRef]

39. Sanuja, S.; Agalya, A.; Umapathy, M.J. Synthesis and characterization of zinc oxide-neem oil-chitosan bionanocomposite for food packaging application. Int. J. Biol. Macromol. 2015, 74, 76-84. [CrossRef]

40. Batista Silva, W.; Cosme Silva, G.M.; Santana, D.B.; Salvador, A.R.; Medeiros, D.B.; Belghith, I.; da Silva, N.M.; Cordeiro, M.H.M.; Misobutsi, G.P. Chitosan delays ripening and ROS production in guava (Psidium guajava L.) fruit. Food Chem. 2018, 242, $232-238$. [CrossRef]

41. Rohani, M.; Zaipun, M.; Norhayati, M. Effect of modified atmosphere on the storage life and quality of Eksotika papaya. J. Trop. Agric. Food Sci. 1997, 25, 103-114.

42. Elsabee, M.Z. Chitosan-Based Edible Films. In Polysaccharides: Bioactivity and Biotechnology; Ramawat, K.G., Mérillon, J.-M., Eds.; Springer International Publishing: Cham, Switerland, 2015; pp. 829-870.

43. Abakar, H.O.M.; Bakhiet, S.E.; Abadi, R.S.M. Antimicrobial activity and minimum inhibitory concentration of Aloe vera sap and leaves using different extracts. J. Pharmacogn. Phytochem. 2017, 6, 298-303.

44. Kaushik, M.; Niranjan, R.; Thangam, R.; Madhan, B.; Pandiyarasan, V.; Ramachandran, C.; Oh, D.-H.; Venkatasubbu, G.D. Investigations on the antimicrobial activity and wound healing potential of ZnO nanoparticles. Appl. Surf. Sci. 2019, 479, 1169-1177. [CrossRef]

45. Lallo da Silva, B.; Abucafy, M.P.; Berbel Manaia, E.; Oshiro Junior, J.A.; Chiari-Andreo, B.G.; Pietro, R.C.R.; Chiavacci, L.A. Relationship between structure and antimicrobial activity of zinc oxide nanoparticles: An overview. Int. J. Nanomed. 2019, 14, 9395-9410. [CrossRef] [PubMed]

46. Guimarães, G.; Dantas, R.; Sousa, A.; Soares, L.; Raylson, D.; Rosana, S.; Lima, R.; Rejane, M.; Beaudry, R.; Silva, S. Impact of cassava starch-alginate based coatings added with ascorbic acid and elicitor on quality and sensory attributes during pineapple storage. Afr. J. Agric. Res. 2017, 12, 664-673. [CrossRef]

47. Mandal, D.; Lalremruata; Hazarika, T.; Nautiyal, B.P. Effect of post-harvest treatments on quality and shelf life of pineapple (Ananas comosus [L.] Merr. 'Giant Kew') fruits at ambient storage condition. Int. J. Bio-Resour. Stress Manag. 2015, 6, 490-496. [CrossRef] 